\title{
Islamic Mini Banking Laboratory Management System:
}

\author{
A Comparative Study
}

\author{
Nur Indah Riwajanti*, Kartika D.S. Susilowati, Riezky Amalia \\ Politeknik Negeri Malang \\ Malang, Indonesia \\ *nur.indah@polinema.ac.id
}

\begin{abstract}
This paper aims to explore the management model of Islamic mini banking laboratory for higher education institutions. Data were collected through interviews with informants from five higher education institutions in East Java and Central Java. The results show that the management model was varied. While the three institutions considered that activities in the Islamic mini bank laboratory are the practical aspect of specific Islamic banking subjects in the curriculum, the other two institutions did not relate it to any subject, but to additional important experiences and skills. There were some challenges in managing the laboratories which are related to inadequate facilities such as computers, a suitable laboratory room, a generator set for supplying electricity when the power goes out, and technical problems in using particular Islamic mini bank computer applications provided by the Islamic bank. To improve student services, some plans are designed, which include developing mini bank's active practices in real-money banking, developing a university-level online system, and providing students with certified skills.
\end{abstract}

Keywords-islamic, mini, banking, laboratory, highereducation institutions

\section{INTRODUCTION}

The Islamic banking industry has expanded significantly over the last few years and contributes to the national economy [1]. This has increased the demand for graduates of Economic Faculty who have practical knowledge and skills related to Islamic banking. In response to this phenomenon, some Higher Education Institutions have developed new study programs or provided subjects focusing on Islamic banking/financial economics. In line with this, there is also an increasing awareness among these institutions about the importance of providing practical expertise in banking operations through the establishment of a mini Islamic banking laboratory. Some of the laboratories cooperate with Islamic Banks, such as BRI Syariah, by providing simulation banking software, namely SALAM BRIs. The framework for SALAM BRIs has been introduced, as part of the Corporate Social Responsibility initiative since 2015, and has been distributed to 82 universities [2].
The purpose of the Islamic Banking Laboratory is to equip students with the understanding and skills on how Islamic Banking Management practices are carried out. An Islamic Bank Laboratory at the Faculty of Economics has been set up to provide students with the experience to contribute to the human capital needed by the Islamic banking world [3]. This simulation-based Islamic banking laboratory is used for practical courses involving lecturers and students as well as part-time workers in the services of the Islamic Bank. The functions performed in the laboratory are thoroughly listed in line with the needs of mini banking, which include management, Islamic Supervisory Board, Manager, Customer Service Officer and Public Relations, Teller and Accounting Workers, Marketing Support, Marketing Financing and Customers. Transactions in the Islamic Bank Laboratory are actual money-based banking transactions to understand Islamic banking practices well. Specifically for the mini banking practice with the Salam BRIs application, the Islamic University of Bandung uses Salam BRIs for students in the 6th Semester of 2014 and 2015 taking 7 classes in the Islamic Mini Bank Laboratory (40 students per class) [4].

The benefits of using laboratory and simulation in the learning process have been discussed previously. Online role play could improve higher education students' knowledge [5-7] and interest in learning particular course [8]. The laboratory learning method using simulation and role-play has been proven to enhance students ' comprehension of the topic in banking, finance and economics $[9,10]$. This approach has also been proven to provide a more detailed understanding when applied in the Accounting field [11]. The curriculum built in the sense of the banking transaction helps students in understanding the subject [12].

It seems, however, that there are variations in how the mini banking laboratory is operated. While some institutions stick to particular subjects' discipline, others tend to use them as a free exercise outside of any subject. Therefore, this paper aims to explore and compare how five Higher Education Institutions in East Java and Central Java with Islamic mini banking manage and operate their laboratories. This research will help devise 
the most effective simulation model and Islamic mini bank management to be applied in the home institution.

\section{METHODS}

This study uses a qualitative analysis approach. The data were collected from both offline and online interviews. Direct observation and interviews were conducted at three Higher Education Institutions in East Java at the beginning of March. Those are the State Islamic University (A), the Private University (B), and a State University (C). Due to global the pandemic impacting all human everyday life and activities, the online interviews were conducted with informants from State Polytechnics (D) and State Islamic Institute (E) in Central Java. Interviews were conducted to collect information on the mini Islamic bank's functioning, the challenges, and the development plan. The informants of this study were the Head of Islamic Mini Banking Laboratories in the of Islamic bank mini-laboratories, who are also a lecturer in Islamic Banking/Finance field at the institutions, and the Head of related Study Program at the above five institutions. They were chosen as informants because of their experiences and responsibilities in managing the mini bank laboratories as well as their ability to assess and relate laboratory function to the teaching learning process. The interviews were conducted between March and July 2020.

Based on the data reduction analysis process, the results of the interview were transcribed and analyzed. The steps include: 1) data reduction by reducing/ summarizing broad data and concentrating on the most relevant details and following a theme; 2) data display by arranging data in a logical relationship pattern to allow data to be interpreted in the form of narration; and 3) conclusion drawing to address the research question [13].

\section{RESULTS AND DISCUSSION}

\section{A. Management System}

Informant A explained that as one of leading Islamic Higher Institutions, the institution has a mini Islamic bank laboratory to facilitate digital transaction practice in a particular subject, namely Banking Laboratory 2 with 3 credits. This laboratory uses Salam BRIs application obtained from BRI Islamic banks. Students use the laboratory once a week after the material to be practiced has been explained at the previous meeting. The total number of sessions is 14 times per semester.

At the beginning of the practice, students fill in their data and the other students' data as customers in the BRIs system, namely the opening of Customer Information File (CIF), followed by other topics about customer service. This laboratory uses a rolling system so that each student will experience a different role in the BRIs Salam application, ranging from the roles as Customer Service, Tellers, etc. They also learn how to count money manually without machines and typing fast. This means that all the skills needed to work at a bank are practiced in the Islamic banking laboratories.
Interestingly, when using the laboratory, the students are asked to wear uniforms to create a working environment. Meanwhile, in the class, they do not need uniforms. Also, the students must follow other instructions such as wearing high heels, neatly cut nails, etc. By using this BRIs system, transactions are carried out online internally on servers in the laboratory. The emphasis is on simulation as explained by the informant as follows:

"This is just simulating how the process to record savings, book-entry...so students can understand the process, there is no need to report and so on. Because there is also no cash savings here...."

The main focus is the students' understanding of the administrative processes and flows carried out in Islamic banks. The laboratory has facilities that can be used by 12 customer service officers, 12 tellers, and a supervisor, meaning that in the laboratory there is only one branch of the bank operating without inter-branch transactions. Because of the limited laboratory capacity, students in one class take turns practicing. One class is divided into 2 shifts; each shift for 30 minutes. In the beginning, the practice is simulated like the beginning of the day a bank opens. In this practice session, students are not asked to do presentations. One sub material in the module is discussed during one meeting.

Informant E explained that a mini Islamic bank laboratory using the BRIs Salam application has been established since 2015. Previously, the faculty had a laboratory but the practice was done manually without using a specific computer application. The laboratory is only one room used for the roleplay to understand how Islamic banks operate, especially the frontline office. The informant $\mathrm{E}$ said that:

"... the establishment of a mini Islamic bank is because there is software offered by BRI Syariah for the practicum process in the laboratory, which is non-credit (SKS). At this time, the faculty already has Islamic banking practicum room, but it does not have software, so the offer of cooperation from BRIS Syariah is the right momentum to develop student skills, especially Islamic banking study programs here.... all types of practicum contain 0 credit (SKS), including mini Islamic banks and under the management of the Laboratory Unit of the Faculty".

The informant $\mathrm{E}$ further clarified that the institution uses a mini banking laboratory independently as a mini Islamic bank practicum that is not attached to one particular subject. Mini Islamic bank practicum is conducted by students to improve skills that are not covered by SKS (course credit) of courses. The informant specifically mentioned that:

"At this institution, the total credits (SKS) taught by the faculty are quite large, because there are some General and Scientific Basic Courses (MKDU) from the institute ... and the numbers are quite large, so, if the credit of bank practicum is added to the SKS, then it will increase the number of credits that must be taken".

Surely, it will burden students if the number of SKS (course credit) taken is too large. In general, students practice Islamic 
banks in semester 6 for 10 meetings. Students who do practices are not only Islamic banking students, but also Islamic accounting and Islamic management students. In technical management, because the Islamic bank mini lab practicum has 0 SKS (course credit), the practicum's technical scheduling is done after scheduling the SKS course is completed. If the credit course is under the responsibility of the Vice Dean I and the Academic division, all practicums at Economic Faculty are managed by the Laboratory Unit in coordination with the Deputy Dean I and the Heads of Departments. In conducting the practicum, the division of roles followed the guidebook from BRI Sharia's; some became CS, tellers and branch heads. Students take turns performing all of these roles. The students use the laboratory for 10 meetings and one group that will remain the same. The simulation model implemented in mini banking only functions with one bank only.

The students of D institution who do practicum are those of Islamic Banking Study Program (2 classes) who take Islamic Bank Laboratory 1 and 2 courses. Islamic mini bank laboratories are also used by all students and students of Banking Finance Study Program (3 classes) who take courses Bank 1 and 2 laboratories for 6 hours per week. Before taking this practical course, students must take prerequisite courses. The Mashrof (Islamic Mobile Banking) Application is used in the laboratory. Simulation systems and role play are used in laboratories by following Standard Operating Procedures (SOP) and teachers' modules; students per group will take turns in carrying out all roles in the bank. During practice, students answer practice questions that have been prepared. Laboratory management is assisted by laboratory staff. Related to students' assessment which is conducted to assess students' achievement, each lecturer has an authority over the assessment.

Informant $\mathrm{C}$ explained that the university's laboratory model is the Islamic Micro Finance Laboratory, where a group of students runs activities such as Islamic mini banking that uses real transactions. The Islamic Micro Finance Laboratory is run with an initial fund of IDR 10 million starting in 2019. The fund has now grown to IDR 15 million over two years. The process of recording in the Islamic Micro Finance laboratory is done manually. This laboratory receives savings from students and provides funding for students who need funds to do business, for example, the production of jackets with a profitsharing scheme (mudharabah). However, students faced difficulties in calculating the profit sharing, as revealed by the informant:

"It turned out that it was difficult to calculate profit sharing based on previous transaction. There was a transaction based on mudarabah. We had a jacket product and has been sold. It turned out that they confused to calculate, how to share the profit".

Funding is provided without collateral. The products are wadiah (deposit) and mudharabah (profit sharing). Students are free to save in any amount, there is no maximum limit. All are welcome to be customers to save in the laboratory.
However, one issues appeared that Informant $\mathrm{C}$ elaborated the following information:

"Yes, indeed the activity was run purely for academics first, so off the business. Later, if we mix it with business, surely there will be some that are tolerated by such terms ... at least our project goals are for the students to understand. Because later they will work, the practice is also different. . .".

Laboratory management is carried out by 18 students with an open recruitment system for one -year working period. A coordinator leads this group. This group of students consists of two groups. So, there is a continuity of information on laboratory operations. This group of students is studying in the sixth semester (class of 2017) and their junior level. So, there is a good regeneration system. Initially, the group members were students of the Islamic Economics study program. However, it has also been opened to non-Islamic Economics students; there were already 5 students. Involvement in the laboratory is voluntary and not an obligation for students. Therefore, banking courses are still theoretical subjects, but students must open savings in the laboratory and get assignments related to laboratory management. The replacement of student groups is done every early December. Training is given to each group who will work in the laboratory. Every day the student's picket is set to guard the laboratory to make transactions.

An interesting aspect of this laboratory is the combination of economic and non-economic activities in the laboratory, as revealed by the informant:

"... in addition to the mini banking activities that we run, we also provide support for studies. We continue to ask them to study like alms writing so they will too. . . because we also don't yet have what is the actual economic pattern, what is the practical economy of Islam ... "

Besides, the students who have an educational background in Islamic boarding schools are assigned to teach Arabic to other students. So, the students can deepen and practice the knowledge gained from Arabic courses. The laboratory also develops collaboration with other faculties in making Zakat applications with concepts made by students and applications made by other students from related faculties. There are two banking-related subjects at this faculty: Islamic Banking in Islamic Economics and Banking Finance study programs.

Regarding role-play in the laboratory, the informant explained that the roles are divided into Customer Service, Tellers, etc. All laboratory members play the roles so that everyone has the same experience. However, recording transactions is done in the savings division. The leader is directly played by the supervisor/instructor, who acts as the informant in this study. Thus, any financing above 5 million must be approved by the informant. If financing is less than 1 million, approval can be given by the group. All financing is still based on trust.

Related to operational hours, the laboratory is open from 9 am to $3 \mathrm{pm}$. So, the students take turns to work in the laboratory. The laboratory will be closed during the school 
holidays. Before closing, a laboratory closing period announcement will be given so that customers can collect savings. Therefore, the group must think about liquidity of funds.

The products offered are wadi'ah, mudarobah, murobahah and ijaroh. However, no one has used ijaroh products. Financing uses murobahah and mudarobah contracts. For example, Murabaha is used to buy plane tickets for students who were delegates of a competition. This loan is secure because it is a bailout that will be paid when the university has disbursed the funds. The practice is still simple. However, integration with related subjects has not been done. The socialization to new students was also carried out to introduce the laboratory as a means of practice for students.

In addition to the mini bank laboratory, there is an entrepreneurial laboratory in the same building. So, there is physical closeness and there appears to be a link between the two laboratories. Practitioners will foster students who have prepared a business plan in the entrepreneurship laboratory. The business plan must be followed in real businesses as graduation output. This is related to the vision declaration as an entrepreneur university. The support from the Chancellor and Dean in encouraging the transformation of laboratories to a space for students to develop their skills is great. Entrepreneurship students are also encouraged to actively participate in start-up funding grants. During the operational activity of the lab, there has never been an unpaid financing.

Informant B explained that the Diploma 3 Banking Study Program has a mini Islamic bank laboratory that allows students to learn mini banking operations manually and also based on a computerized system. The students must learn the basic philosophy of the manual because this is the basic knowledge before doing the procedure in computerized system. Practicing in the Islamic mini bank laboratories is included in the Islamic Bank Practices course (manually) and Advanced Islamic Bank Practices (computerized). One class is divided into 2 groups; each consists of 13 students. When students in one group are practicing as bank employees, other students in the other group act as customers. Learning models in the laboratory use role-play with the roles as Customer Service, Teller, Leadership, Accounting and Financing. One semester consists of 12 times face-to-face and 2 examinations for 200 minutes of each session. Computer applications used in this laboratory were developed based on the laboratory requirements. There is also a mini bank lab which is run together with BNI Syariah, where students learn about Islamic banks' transaction process from the beginning to end process. Operations at BNI Syariah are conducted directly by BNI Syariah for transactions within this University.

\section{B. Challenges}

In managing the laboratory there are different obstacles were found in the institutions. Informant $\mathrm{C}$ explained that they experienced problems when the topics presented in class are different from those carried out in the laboratory. Therefore, the laboratory assistant re-explains the topic so that the students can understand them. Another problem is related to computer facilities in the laboratory. Only 10 computers are available, so one computer is used by 2 students.

Informant $\mathrm{E}$ explained that the Islamic Bank mini laboratory unit has constraints related to infrastructure because the laboratory does not have a generator set. When electricity from PLN is not available, the practicum is closed. Because this practicum does not have credit (SKS), the schedule adjusts to the student schedule. Furthermore, because the space used by the mini bank practicum is an integrated computer laboratory and is used by all faculties with a variety of different practicum computer applications, technical constraints often occur, so that it cannot be used optimally. Challenges in terms of teaching are that the teaching team cannot fully teach because of the large number of students and limited time. Therefore, the laboratory unit recruits 8th-semester students trained by BRIS Syariah trainers to provide assistance in the laboratory. The informant stated this:

"So, of course, from the teaching side, not full teaching from BRIS. the lecturers cannot even take part in teaching, due to time constraints already full teaching SKS courses."

The students' obstacle is that software can only be used in the laboratory room, so they cannot learn outside the -campus. The BRIs application's operationalization obstacle is that it is only a one-time error application, and BRIS immediately corrects it. At the time of the interview, the application had been used for 5 years since 2015, and there was no update from BRI Sharia's.

Informant D claimed that he did not experience significant obstacles and that everything could be run well. This happened because the laboratory has been running for a long time to find the best management pattern and follow the institution's needs. Also, this institution uses different applications and does not depend on certain banks as partners.

Informant $\mathrm{C}$ stated that there were problems in operating the BRIs Salam application which technically had not been applied in classroom learning. The informant mentioned that this application was just received in 2019. The Economic Faculty has received assistance with the applications installed on the server, but permanent laboratory rooms are not yet available, as explained by the informant:

"...related to the SALAM BRIS we don't have a definite laboratory... the application is installed on the computer tablet...".

Another problem is that the application is inaccessible and sometimes experiences technical difficulties. Systematically, if it has not been used for a long time, students cannot access it. So, they must contact BRI Syariah in Jakarta to assist with application access. Until now, only students engaged in laboratory received training from BRI. The obstacle is also related to IT's technical aspects, which is the cut off of the network being. When searching for a solution to the problem, it turns out that it must be related to the Bank's center Office in 
Jakarta, and until the interview was done there was no solution. The informant $\mathrm{C}$ further explained that:

"Yes, the maintenance of IT...we haven't received the intention for PICs on campus for maintenance, so we have to ask to BRI Syariah... The same thing has actually been experienced in cooperation with BRI conventional... So I think, attention must be given to internal maintenance..."

The informant concluded that BRI emphasized the procedural aspects when a problem occurred. Another thing that is more difficult is that the IT department is located in the Central Office of BRI in Jakarta.

In addition, informant $\mathrm{C}$ also informed that it does not use the Salam applications because the Study Programs expects to get application programs that are more in line with the needs of the faculty, as stated by the informants as follows:

"...lesson learn from previous lecture... it turns out that when we saw the activity, it tended to be for front line activities... thus, the head of Study Program was less satisfying ...yesterday we were asking for what should be for higher level...so the application should be able to conduct analysis process, ...we asked for those related to risk management and treasury which is more focused on such analysis ... ".

The solution is inviting practitioners as guest lecturers, for example, from BRI, as instructors in certain subjects. Practitioners as external lecturers teach certain topics that require practitioners' views. Another solution is conducting comparative studies by visiting institutions related to banking, such as Bank Indonesia, to learn about the payment system.

The same problem is faced by informant B from Private University. Similar to informant C's experience, the Salam BRIs application was also received, including training for teachers, but due to operational constraints that could not be overcome, the application was not used until now.

\section{Future Plans}

The informants explained the development plans for the current laboratory. Informant A explained that the regular mini bank practicum was carried out according to the existing module, starting with Training of Trainer activities with presenters from the BRIS, initial meeting of basic materials from the presenters from BRIS, to Salam BRIs practices. For future development, active Mini bank practices will be designed, in which students will become agents of BRIS to open accounts and other banking transactions.

Informant $\mathrm{D}$ explained that the institution plans to conduct real transactions using rupiah funds and students can open savings at their respective places. For this reason, the institution will cooperate with Islamic Cooperative and banks. The informant underlined that:

"Students expect to do real cash transaction, because we already have Poli-pay...then, schedule can be set for all students to provides services for transaction using Poli-pay transactions ...".
Because it already has a mini laboratory with real transactions, informant $\mathrm{C}$ explained that there is a plan for developing an Islamic micro laboratory to create a centralized integrated online system for all students at the university. In addition, there are also plans to provide certification for students as evidence of their skills. This certificate will be useful for students when they graduate and apply for jobs related to Islamic banking.

\section{CONCLUSION}

The result shows that the management model was varied; while the three institutions considered that activities in the Islamic mini bank laboratory are the practical aspect related to specific Islamic banking subjects in the curriculum, the other two institutions do not relate it to any subject but to different essential experiences and skills for students. Some challenges in managing the laboratory include inadequate facilities such as computers, suitable laboratory room, generator for providing electricity when the power goes out, and technical problems in using particular Islamic mini bank computer application provided by the Islamic bank. All the sample institutions apply mini banking applications only for one branch bank transaction and do not include interbank transactions. To improve student services, some plans are developed, which include developing mini bank's active practices in real-money banking, developing a university-level online system, and providing students with certification skills.

\section{ACKNOWLEDGMENT}

The authors would like to thank State Polytechnics of Malang for supporting and providing funding for this research.

\section{REFERENCES}

[1] S. El Ayyubi, L. Anggraeni, and A.D. Mahiswari, "Pengaruh Bank Syariah terhadap Pertumbuhan Ekonomi di Indonesia," Al-Muzara'ah, vol. 5 , no. 2 , pp. $88-106,2018$.

[2] E. Fauziah, I.H. Senjiati, and S.R. Febriadi, "Efektifitas Program CSR Salam BRIS Pada Peningkatan Kompetensi Mahasiswa Di Laboratorium Bank Mini Syariah," Amwaluna: Jurnal Ekonomi dan Keuangan Syariah, vol. 2, no. 1, pp. 88-104, 2018.

[3] I. Zuhroh, "Penguatan Laboratorium Bank Syariah Untuk Mendukung Perkembangan Industri Keuangan Syariah," Journal of Innovation in Business and Economics, vol. 3, no. 1, 2012

[4] E. Fauziah, I.H. Senjiati, and S.R. Febriadi, "Model Pemberdayaan Laboratorium Bank Mini Syariah di Perguruan Tinggi," Muqtasid: Jurnal Ekonomi dan Perbankan Syariah, vol. 8, no. 2, 2018.

[5] C. Russel and J. Shepherd, "Online role-play environment for highe education," British Journal of Education Technology, vol. 41, no. 6, pp 992-1002, 2010.

[6] S.D. Dolvin and M.K. Pyles, "The impact of imulation activity on student performance," Journal of Economics and Economic Education Research, vol. 19, no. 3, pp. 1-10, 2018.

[7] D. Druckman and N. Ebner, "Discovery learning in management education: Design and case analysis," Journal of Management Education, vol. 42, no. 3, pp. 347-54, 2018. 
[8] S. Dolvin and M. Phyles, "The influence of simulation acitivity on student interest," Journal of Economics and Economic Education Research, vol. 12, no. 3, pp. 35-48, 2011.

[9] Badriatin, "Online Trading Mata Kuliah Pasar Modal," Jurnal Ilmu Management dan Akuntansi, vol. 7, no. 2, pp. 69-75, 2019.

[10] D. Wulandari, B.S. Narmaditya, Using Simulation Methods to Improve Student Learning. 2016, p. 1-6.
[11] K. Septyan, "Model Laboratorium Akuntansi Terintegrasi untuk Perguruan Tinggi," Jurnal Akuntansi, vol. 7, no. 1, pp. 20-9, 2019.

[12] A.D.S. Arini, "Pengembangan Modul Berbasis Pendekatan Saintifik Sebagai Bahan Ajar Materi Rekonsiliasi Bank," Jurnal Pendidikan Akuntansi, vol. 3, no. 2, pp. 1-6, 2015.

[13] H.B. Miles, A.M. Huberman, and J. Saldana, Qualitative Data Analysis, A Method Sourcebook, third Edition. 3rd Edition ed. California: SAGE, 2014. 